\title{
The effect of conjugated linoleic acid, acetate, and their interaction on adipose tissue lipid metabolism in nonlactating cows
}

\author{
N. Urrutia, ${ }^{1}$ Y. Ying, ${ }^{2}$ and K. J. Harvatine ${ }^{3}$ \\ Department of Animal Science, Penn State University, University Park 16802
}

\begin{abstract}
During biohydrogenation-induced milk fat depression, adipose tissue lipogenesis may be increased through nutrients spared from milk fat synthesis. However, the direct effect of trans-10, cis-12 conjugated linoleic acid (CLA) and the indirect effect of spared nutrients on adipose tissue lipogenesis during milk fat depression is not clear. The objective of this study was to determine the direct effect of CLA, spared acetate, and their interaction on adipose tissue lipogenesis using nonlactating dairy cows as an experimental model, which allows separation of the effect of CLA and nutrient sparing. Eight ruminally cannulated, multiparous nonlactating and pregnant Holstein cows were randomly assigned to treatments in a $4 \times 4$ Latin square design with a 2 $\times 2$ factorial arrangement of treatments. Factors were CLA and acetate, and treatments were control (CON), rumen acetate infusions (Ac; continuous infusion of 7 $\mathrm{mol} / \mathrm{d}$ adjusted to $\mathrm{pH} 6.1$ with sodium hydroxide), abomasal infusion of trans-10,cis-12 CLA (CLA; $10 \mathrm{~g} / \mathrm{d}$ of both trans-10,cis-12 CLA and cis-9,trans-11 CLA), and Ac + CLA (Ac + CLA). Dry matter intake was not affected by Ac, but tended to decrease by CLA. Plasma trans-10, cis-12 CLA concentration as a percentage of fatty acids was increased by 0.3 percentage points by CLA. No treatment effect was observed on plasma glucose and $\beta$-hydroxybutyrate, but an interaction was observed of CLA and Ac on plasma insulin and nonesterified fatty acids. Insulin was increased $24 \%$ by CLA, but not by Ac + CLA, and nonesterified fatty acids were increased $55 \%$ by Ac + CLA, but not by CLA alone. Lipogenesis and oxidation capacity of adipose tissue explants were not affected by treatments.
\end{abstract}

\footnotetext{
Received October 30, 2016.

Accepted March 1, 2017.

${ }^{1}$ Current address: Instituto de Investigaciones Agropecuarias, INIA Remehue, Osorno, Chile.

${ }^{2}$ Current address: Department of Medicine, Penn Center for Pulmonary Biology, Penn Cardiovascular Institute, University of Pennsylvania, Philadelphia 19104.

${ }^{3}$ Corresponding author: kjh182@psu.edu
}

Adipose expression of key lipogenic factors (peroxisome proliferator-activated receptor $\gamma 2$ and sterol response element binding protein 1c) were reduced by CLA, by the interaction of Ac and CLA (sterol response element binding protein 1c), and tended to be reduced with Ac (S14 and peroxisome proliferator-activated receptor $\gamma 1$ ). Expression of several adipose lipogenic enzymes (fatty acid synthase, acetyl-CoA carboxylase, and stearoyl-CoA desaturase 1) was reduced by CLA and Ac. An interaction was observed of Ac and CLA for fatty acid binding protein 4 , which was decreased by Ac, but not Ac + CLA. In conclusion, in the nonlactating cow, adipose tissue is sensitive to the anti-lipogenic effects of trans-10,cis-12 CLA at the transcription level and acetate does not stimulate lipogenesis.

Key words: acetate, conjugated linoleic acid, adipose lipogenesis, spared nutrient

\section{INTRODUCTION}

Biohydrogenation (BH) induced milk fat depression (MFD) results in a specific decrease in milk fat synthesis in lactating dairy cows and trans-10, cis-12 CLA is the most well studied bioactive fatty acid (FA) that causes the condition. Milk fat originates either from de novo synthesis in the mammary gland or mammary uptake of preformed FA originating from the diet and mobilization of body fat reserves (Emery, 1973). During BH-induced MFD, yield of both preformed and de novo synthesized FA are decreased, although de novo synthesized FA are decreased to a larger extent. The mechanism involves a decrease in mammary lipogenic capacity and expression of key lipogenic factors, including sterol response element binding protein 1 (SREBP1) and thyroid hormone responsive spot 14 (S14), and lipid synthesis enzymes, including fatty acid synthase $(F A S N)$, acetyl-CoA carboxylase $(A C C)$, stearoyl-CoA desaturase 1 ( $S C D 1)$, lipoprotein lipase $(L P L)$, fatty acid binding protein 4 (FABP4), and glycerol phosphate acyl transferase (GPAT; reviewed by Harvatine et al., 2009a).

The decrease in milk fat synthesis during BH-induced MFD decreases mammary demand for nutrients used 
for milk fat synthesis. This decrease in demand spares a large amount of acetate and also butyrate, glucose, and preformed FA, which are then available to other tissues for other metabolic uses. Spared nutrients and the associated increase in energy balance are expected to feedback to reduce intake, and Harvatine et al. (2009b) observed a small decrease in intake in a meta-analysis of short-term CLA infusion experiments (3 to 5 d). However, the decrease in intake only accounted for a portion of the nutrients spared by the reduction in milk fat observed. Additionally, Harvatine et al. (2009b) reported an increase in expression of key lipogenic factors [SREBP1,S14, and peroxisome proliferator-activated receptor gamma $(P P A R \gamma)]$, lipogenic enzymes $(F A S N$, $L P L, S C D 1$, and $F A B P 4$ ), and leptin in adipose tissue during CLA-induced MFD. Thering et al. (2009) also reported increased expression of $\mathrm{S} 14$ in adipose tissue during long-term $\mathrm{BH}$-induced MFD, although the experiment used a limited number of cows and failed to observe changes in other lipogenic genes.

Increased expression of lipid synthesis genes in adipose tissue during trans-10, cis-12 CLA infusion in the cow is in contrast to its well-described inhibition of lipid synthesis and adiposity in other animal models including the pig, rodents, and humans (Foote et al., 2010). Additionally, CLA decreased lipogenic capacity in ex-vivo treated adipose tissue explants from beef steers (Choi et al., 2014). Importantly, these models are different from CLA-induced MFD as they do not have the confounding effect of spared nutrients and also used higher doses of CLA.

Harvatine et al. (2009b) proposed that increased expression of lipogenic genes in adipose tissue during CLA-induced MFD might represent a short-term response to nutrients spared from milk fat synthesis or that adipose tissue sensitivity to trans-10, cis-12 CLA might differ from that of mammary tissue in the lactating cow. However, significant confusion exists about the effect of trans-10,cis-12 CLA and spared nutrients on adipose tissue lipogenesis during MFD. It is not possible to separate the direct effect of CLA from spared nutrients in the lactating cow; thus, nonlactating cows were used in the current experiment. The objective of this study was to determine the direct effect of CLA, spared acetate, and their interaction on adipose tissue lipogenesis using nonlactating dairy cows. Our hypothesis was that the trans-10,cis-12 CLA dose that causes MFD in the lactating cow would reduce adipose tissue lipogenesis in the nonlactating cow and that acetate infusion mimicking the amount of acetate spared during MFD would increase adipose tissue lipogenesis and expression of lipogenic genes.

\section{MATERIALS AND METHODS}

\section{Experimental Design and Treatments}

All experimental procedures were approved by the Pennsylvania State University Institutional Animal Care and Use Committee (\#41727). Eight ruminally cannulated multiparous Holstein cows (305-d energycorrected milk yield of previous lactation: 11,206 \pm $3,191 \mathrm{~kg}$, average $\pm \mathrm{SD}$ ) were randomly assigned to treatments in a $4 \times 4$ Latin square design with a $2 \times$ 2 factorial arrangement of treatments testing the effect of ruminal acetate and abomasal trans-10, cis-12 CLA infusion. Treatments included the following: control $(\mathbf{C O N})$, rumen acetate infusions $(\mathbf{A c})$, abomasal trans-10, cis-12 CLA infusions (CLA), and Ac + CLA $(\mathbf{A c}+\mathbf{C L A})$. During treatment periods, cows were housed in a tie-stall metabolism unit located at the Pennsylvania State University Dairy Production Research and Teaching Center. Experimental periods were $10 \mathrm{~d}$ in length and included $3 \mathrm{~d}$ of treatment and $7 \mathrm{~d}$ of washout. Cows were arranged in 4 blocks based on expected calving date (between March 2013 and July 2014). Average dry period length was $115 \pm 54 \mathrm{~d}$ and calf weight was $41.5 \pm 3.1 \mathrm{~kg}$ (average $\pm \mathrm{SD}$ ).

The Ac treatment provided $7 \mathrm{~mol} / \mathrm{d}$ of acetate and was prepared by diluting $400 \mathrm{~mL}$ of acetic acid in $7 \mathrm{~L}$ of distilled water and then adjusted to $\mathrm{pH} 6.1$ using $269 \mathrm{~g}$ of sodium hydroxide pellets (J. T. Baker, Phillipsburg, PA). The CON and CLA treatments received an equal volume of distilled water. Acetate or distilled water were continuously infused through the rumen cannula using acid-resistant tubing (Norprene L/S 14, Cole-Parmer, Vernon Hills, IL) and peristaltic pumps (Masterflex L/S drive 7520-35, Cole-Parmer) similar to Sheperd and Combs (1998). The CLA treatment consisted of abomasal infusion of $34 \mathrm{~g} / \mathrm{d}$ of a CLA methyl ester stock (Lutalin, BASF, Lampertheim, Germany) that contained $30 \%$ trans-10, cis-12 CLA and $30 \%$ cis9,trans-11 CLA to provide $10 \mathrm{~g} / \mathrm{d}$ of trans-10, cis-12 CLA. The CLA stock was infused in equal doses every $4 \mathrm{~h}$ through an abomasal infusion line $[0.5 \mathrm{~cm}$ (i.d.) polyvinyl chloride tubing (Spires et al., 1975)] placed through the rumen cannula. The infusion lines were inserted the day before initiation of treatments and placement in the abomasum was checked daily. The lines were rinsed with $50 \mathrm{~mL}$ of warm distilled water before and after CLA infusion and with $20 \mathrm{~mL}$ of $70 \%$ ethanol before the final water rinse. In addition, $\mathrm{CON}$ and Ac treatments received $100 \mathrm{~mL}$ of warm distilled water and $20 \mathrm{~mL}$ of $70 \%$ ethanol abomasally as a handling control. 


\section{Feed Sampling and Analysis}

Cows were fed individually once daily $(0900 \mathrm{~h})$ at $110 \%$ of expected intake and refusals were recorded daily. Forage and base diet DM concentration was determined weekly for diet adjustment and DMI determination $\left(72 \mathrm{~h}\right.$ in a forced-air oven at $\left.55^{\circ} \mathrm{C}\right)$. All individual feed ingredients were sampled by period and composited for analysis of $\mathrm{CP}, \mathrm{NDF}$, and ADF by wet chemistry procedures (Cumberland Valley Analytical Services Inc., Maugansville, MD). Briefly, CP and ADF was determined according to AOAC International (2000), and NDF according to Van Soest et al. (1991) using heat-stable amylase and sodium sulfite. Starch was determined by an enzymatic method (Karkalas, 1985) using Hazyme enzyme (Centerchem, Norwalk, $\mathrm{CT}$ ), after samples were gelatinized with sodium hydroxide. Ingredient and nutrient composition of the 4 diets is reported in Table 1. Fatty acid composition of feed ingredients was determined as in Rico and Harvatine (2013) and is reported in Supplemental Table S1 (https://doi.org/10.3168/jds.2016-12232).

\section{Adipose Tissue Biopsies}

Adipose tissue biopsies were collected at the end of each treatment period. The biopsy was taken from the tail-head region as described by Harvatine et al. (2009b), and sides were alternated between periods. Briefly, cows were sedated with xylazine (0.5 to 1 $\mathrm{mg} / 45 \mathrm{~kg}$ of BW i.v.) and provided with local subcutaneous anesthesia administered in a circular pattern around the incision site $(15 \mathrm{~mL}$, lidocaine hydrochloride $2 \%$ ). Once the anesthesia was effective, an incision was made in the skin and adipose tissue was dissected. The adipose tissue sample ( 1 to $1.5 \mathrm{~g}$ ) was rinsed in sterile $0.9 \%$ saline. Two subsamples were snap-frozen in liquid nitrogen and subsequently stored at $-80^{\circ} \mathrm{C}$ until RNA extraction and a portion was placed in saline transport buffer $(0.9 \% \mathrm{NaCl}, 25 \mathrm{~m} M$ HEPES, $\mathrm{pH}$ $7.4,37^{\circ} \mathrm{C}$ ) for immediate use in the lipogenesis assay as described below. The incision was irrigated and closed with polyglactin 910 suture (Ethicon Vicryl 0, Johnson \& Johnson, Somerville, NJ) using simple interrupted stitches.

Table 1. Ingredient and nutrient composition of experimental diets ${ }^{1}$

\begin{tabular}{|c|c|c|c|c|}
\hline Variable & Block 1 & Block 2 & Block 3 & Block 4 \\
\hline \multicolumn{5}{|l|}{ Ingredient ( $\%$ of $\mathrm{DM})$} \\
\hline Straw & 39.5 & 21.2 & 15.8 & 8.0 \\
\hline Grass silage & - & 53.8 & 49.1 & 19.4 \\
\hline Corn silage & 28.3 & - & 14.4 & - \\
\hline Sorghum-Sudan silage & - & - & - & 50.6 \\
\hline Canola meal & 15.3 & 15.4 & 12.2 & 9.8 \\
\hline Cottonseed hulls & 8.2 & - & - & - \\
\hline Cracked corn & - & 4.0 & - & 6.2 \\
\hline Bakery by-product ${ }^{2}$ & 3.2 & - & 2.6 & - \\
\hline Cane molasses & 4.6 & 4.6 & 4.6 & 4.6 \\
\hline Mineral-vitamin $\operatorname{mix}^{3}$ & 0.9 & 0.9 & 1.3 & 1.3 \\
\hline \multicolumn{5}{|l|}{ Composition (\% of DM) } \\
\hline Forage & 67.8 & 75.0 & 79.3 & 78.0 \\
\hline $\mathrm{NDF}$ & 51.8 & 53.6 & 50.9 & 54.0 \\
\hline $\mathrm{ADF}$ & 35.8 & 35.9 & 34.2 & 33.8 \\
\hline $\mathrm{CP}$ & 13.8 & 16.3 & 15.7 & 14.1 \\
\hline Starch & 10.9 & 4.3 & 6.3 & 5.5 \\
\hline Fatty acids ${ }^{4}$ & 2.1 & 1.6 & 2.0 & 1.6 \\
\hline
\end{tabular}

${ }^{1}$ Each cow was fed the same diet during experimental periods. Four different diets were fed through the course of the experiment to the 4 blocks of cows used (March 2013 to July 2014). A block by treatment interaction was tested in the statistical model and was not significant.

${ }^{2}$ Contained (g/100 g of DM): $17 \%$ CP, $28.2 \%$ ADF, $39.1 \%$ NDF, $11 \%$ fatty acids, and $20 \%$ starch.

${ }^{3}$ Contained (as-fed basis): $46.33 \%$ dried corn distillers grains, $24.91 \%$ calcium carbonate, $12.92 \%$ magnesium oxide, $12.6 \%$ salt, $0.85 \%$ zinc sulfate, $0.67 \%$ rumensin, $0.36 \%$ ferrous sulfate, $0.34 \%$ manganese sulfate, $0.25 \%$ copper sulfate, $0.20 \%$ mineral oil, $0.05 \%$ selenium mix, $0.03 \%$ vitamin $\mathrm{AD}$ mix, $0.01 \%$ calcium iodate, $0.38 \%$ vitamin E mix [composition (DM basis): $11.1 \% \mathrm{CP}, 11 \% \mathrm{NDF}, 5.65 \% \mathrm{ADF}, 10.2 \% \mathrm{Ca}, 0.36 \% \mathrm{P}, 7.47 \% \mathrm{Mg}$, $0.49 \% \mathrm{~K}, 0.7 \% \mathrm{~S}, 631 \mathrm{mg} / \mathrm{kg}$ of Cu, 3,084 mg/kg of Zn, $1,158 \mathrm{mg} / \mathrm{kg}$ of Fe, $15.5 \mathrm{mg} / \mathrm{kg}$ of Se, 305,482 IU $/ \mathrm{kg}$ of vitamin A (retinyl acetate), 76,008 IU $/ \mathrm{kg}$ of vitamin D (activated 7-dehydrocholesterol), and 1,916 IU $/ \mathrm{kg}$ of vitamin E (DL- $\alpha$ tocopheryl acetate)].

${ }^{4}$ Total fatty acid content was determined using 2 internal standards and quantified by GC-flame ionization detector. 


\section{Adipose Tissue Explant Incubation}

A portion of the adipose tissue was used within $30 \mathrm{~min}$ to determine acetate incorporation into FA and oxidation to $\mathrm{CO}_{2}$ as previously described (Bauman et al., 1973; Ingle et al., 1973). Briefly, tissue explants were sliced using a Stadie-Riggs hand microtome (Thomas Scientific, Swedesboro, NJ), weighed, and incubated in triplicates (approximately $100 \mathrm{mg}$ ) in flasks containing $3 \mathrm{~mL}$ of freshly prepared (daily) Krebs-Ringer bicarbonate buffer ( $\mathrm{pH}$ 7.4) plus $20 \mathrm{mM}$ HEPES, $10 \mathrm{~m} M$ acetate, $5 \mathrm{mM}$ glucose, $2 \mu \mathrm{g} / \mathrm{mL}$ of insulin, and $1-{ }^{14} \mathrm{C}$ acetate $(0.33 \mu \mathrm{Ci} / \mathrm{mL}$; American Radiolabeled Chemicals Inc., St. Louis, MO). Flasks were gassed $\left(\mathrm{O}_{2}\right.$ and $\left.\mathrm{CO}_{2}, 95: 5\right)$ and sealed with rubber caps equipped with a plastic hanging well containing a $2 \times 2 \mathrm{~cm}$ piece of filter paper for capture and measurement of ${ }^{14} \mathrm{CO}_{2}$. Incubation was performed in a shaking water bath at $37^{\circ} \mathrm{C}$ for $3 \mathrm{~h}$, terminated with addition of $250 \mu \mathrm{L}$ of $0.5 \mathrm{M}$ sulfuric acid, and $\mathrm{CO}_{2}$ was trapped by addition of $100 \mu \mathrm{L}$ of $25 \%$ potassium hydroxide to filter paper in the hanging wells. Lipids were extracted in petroleum ether and radioactivity of lipids and filter paper were quantified as described by Bauman et al. (1970).

\section{Gene Expression Analysis}

Total RNA was isolated from approximately $250 \mathrm{mg}$ of adipose tissue using the EZNA Total RNA Kit II with on-column DNase treatment (Omega Bio-Tek, Norcross, GA). The RNA concentration and integrity were determined by an Experion Automated Electrophoresis Station (Bio-Rad, Hercules, CA). Total RNA was reverse transcribed using the High-Capacity cDNA Reverse Transcription Kit with random primers (Applied Biosystems, Foster City, CA). Real-time quantitative PCR reactions were conducted using PerfeCTa SYBR Green SuperMix with ROX (Quanta Biosciences, Gaithersburg, MD) in an Applied Biosystems 7900HT Fast Real-Time PCR System (Applied Biosystems) and $400 \mathrm{n} M$ of previously validated gene-specific forward and reverse primers (Supplemental Table S2, https:// doi.org/10.3168/jds.2016-12232; Invitrogen, Carlsbad, CA). Other primers were designed using primer-BLAST (National Center for Biotechnology Information) and validated for efficiency and a single product by melting curve analysis.

Sample message level was determined relative to a dilution curve of pooled cDNA and analyzed relative to the geometric mean of 2 housekeeping genes [ribosomal protein 9 (RPS9) and 32-microglobulin (B2M)].

\section{Blood Sampling and Analysis}

Blood samples were collected from the tail vein using potassium EDTA tubes (Greiner Bio-One North America Inc., Monroe, NC) 6 times over d 2 and 3 of each period to represent every $4 \mathrm{~h}$ of a day $(0000,0400$, 0800, 1200, 1600, and $2000 \mathrm{~h}$ ). Blood was immediately placed on ice, centrifuged within $30 \mathrm{~min}$ at $1,300 \times g$ for $15 \mathrm{~min}$ at $4^{\circ} \mathrm{C}$, and plasma harvested and stored at $-20^{\circ} \mathrm{C}$ until laboratory analysis. Prior to analysis, plasma samples were composited by cow within period. Composited plasma samples were analyzed for insulin (Mercodia Bovine Insulin ELISA; Mercodia AB, Uppsala, Sweden), glucose [PGO Enzyme procedure no. P 7119; Sigma-Aldrich, St. Louis, MO (Raabo and Terkildsen, 1960)], nonesterified fatty acids (NEFA; Wako HR Series NEFA-HR kit, Wako Chemicals USA, Richmond, VA) as modified by Ballou et al. (2009), BHB (procedure \#2440, Stanbio Laboratory, Boerne, TX), phospholipids (Phospholipids C, Wako Chemicals USA, Richmond, VA), triglycerides (L-Type TG M, Wako Chemicals USA), and free cholesterol (Free Cholesterol E, Wako Chemicals USA).

Total plasma FA profile was determined by extraction of $1 \mathrm{~mL}$ of plasma with hexane:isopropanol with methyl tridecenoate and nonadecanoate acid as internal standards (NuChek Prep Inc., Elysian, MN). Fatty acids were directly methylated in a dual methylation procedure using $0.5 \mathrm{M}$ sodium methoxide in methanol at $50^{\circ} \mathrm{C}$ for 10 min followed by $5 \%$ methanolic $\mathrm{HCl}$ at $80^{\circ} \mathrm{C}$ for $10 \mathrm{~min}$ (Kramer et al., 1997). Fatty acid methyl esters were quantified by GC with a flame ionization detector and a capillary column [SP-2560; $100 \mathrm{~m} \times$ $0.25 \mathrm{~mm}$ (i.d.) with $0.2-\mu \mathrm{m}$ film thickness; Supelco Inc., Bellefonte, PA]. Initial oven temperature was $70^{\circ} \mathrm{C}$, increased $8^{\circ} \mathrm{C} / \mathrm{min}$ to $110^{\circ} \mathrm{C}$, increased $5^{\circ} \mathrm{C} / \mathrm{min}$ to $170^{\circ} \mathrm{C}$ for $10 \mathrm{~min}$, and increased $4^{\circ} \mathrm{C} / \mathrm{min}$ to $215^{\circ} \mathrm{C}$ for $25 \mathrm{~min}$. Inlet and detector temperatures were $250^{\circ} \mathrm{C}$ with a $50: 1$ split ratio. Peaks were identified using FAME standards (GLC 68D and 780 and pure trans-10,cis-12 CLA and cis-9,trans-11 CLA, NuChek Prep Inc.; Bacterial Acid Methyl Ester Mix, 47080-U, Sigma-Aldrich Inc.; and GLC 110 mixture, Matreya LLC, State College, PA) and recoveries of individual FA were determined using an equal weight reference standard (GLC 461; NuChek Prep Inc.).

\section{Statistical Analysis}

Data were analyzed as a factorial experiment using REML and the fit model procedure of JMP (version 10.0.2, SAS Institute Inc.). The model included the 
random effect of cow, period, and block and the fixed effect of the main factors Ac, CLA, and their interaction $(\mathrm{CLA} \times \mathrm{Ac})$. For gene expression, the model also included the geometric mean of B2M and RPS9 as a fixed effect (covariant). The interaction of block and treatment was tested because the experiment was conducted in 4 blocks of animals throughout March 2013 to July 2014. The interaction was not significant and therefore removed from the model. For tissue incubation and gene expression data, data were log-transformed for analysis and back-transformed data are reported. Data points with studentized residuals outside of \pm 2.5 for tissue incubation and gene expression and \pm 3.5 for all other data were considered outliers and excluded from analysis. Differences were declared significant at $P$ $\leq 0.05$ and tendencies at $P \leq 0.10$ for both main effects $(\mathrm{Ac}, \mathrm{CLA})$ and interactions $(\mathrm{Ac} \times \mathrm{CLA})$.

\section{RESULTS AND DISCUSSION}

Treatments were designed to provide trans-10, cis-12 CLA at the dose sufficient to induce near maximal MFD in a lactating cow and to provide acetate similar to that spared during near maximal MFD to measure the direct effects of Ac and CLA and their interaction in adipose tissue of nonlactating cows (Baumgard et al., 2001). The Ac + CLA treatment mimicked the CLAinduced MFD state. Using nonlactating cows allowed separation of the effect of CLA and spared nutrients that occur during CLA-induced MFD in the lactating cow. The acetate dose $(7 \mathrm{~mol} / \mathrm{d}=424 \mathrm{~g} / \mathrm{d})$ represents the amount of acetate spared during MFD induced by $10 \mathrm{~g} / \mathrm{d}$ of trans-10, cis-12 CLA for an average cow [36 $\mathrm{kg}$ of milk/d; $3.5 \%$ to $1.9 \%$ milk fat (Baumgard et al., 2000; Baumgard et al., 2001)] based on the stoichiometry of de novo lipogenesis as described by Baldwin (1995).

Dry matter intake was $14.1,13.8,15.3$, and 13.9 $\mathrm{kg} / \mathrm{d}(\mathrm{SE}=1.1)$ for CON, CLA, Ac, and Ac + CLA, respectively. We observed a tendency for CLA to reduce DMI $(P=0.08)$, but no effect was observed of Ac or interaction of Ac and CLA. Although intake is normally not decreased in individual experiments, a tendency for reduced DMI without a reduction in milk yield in lactating cows has been previously reported, where $5 \mathrm{~g} / \mathrm{d}$ of trans-10,cis-12 CLA tended to reduce intake by $0.8 \mathrm{~kg} / \mathrm{d}$ (Perfield et al., 2007) and $10 \mathrm{~g} / \mathrm{d}$ of trans-10,cis-12 CLA tended to reduce intake by 4.4 $\mathrm{kg} / \mathrm{d}$ (Baumgard et al., 2000). Additionally, Harvatine et al. (2009b) observed a small decrease in intake in a meta-analysis of 14 short-term lactating cow studies involving abomasal CLA infusion, where nutrients spared from milk fat synthesis are expected to feedback to reduced intake. Dietary CLA also reduces intake in rodents (Foote et al., 2010), but not in pigs (Ostrowska et al., 1999, Corl et al., 2008); however, those experiments use higher doses that resulted in major decreases in adipose tissue and the mechanism of intake depression was not investigated.

\section{Plasma CLA, Hormones, and Metabolites}

The CLA treatment increased plasma trans-10, cis-12 CLA by 0.28 percentage points and cis-9,trans- 11 CLA by 0.38 percentage points (as \% of identified FA; Table 2). Harvatine and Bauman (2011) reported that abomasal infusion of $15 \mathrm{~g} / \mathrm{d}$ of trans-10,cis-12 CLA increased plasma trans-10,cis-12 CLA 0.17 percentage points in mid-lactation cows. Also, a dose of $10 \mathrm{~g} / \mathrm{d}$ of trans-10,cis-12 CLA of the same CLA stock used in the current experiment increased plasma cis-9,trans-11 CLA and trans-10,cis-12 CLA by 0.10 percentage points in lactating cows [from 0.10 to $0.21 \%$ and $<0.01$ to $0.10 \%$, respectively (Urrutia et al., 2015)]. The higher enrichment of CLA isomers in plasma in the current experiment was expected because CLA was not secreted in milk; however, it is interesting that plasma cis-9,trans-11 CLA increased more than trans-10,cis-12 CLA. Additionally, trans-10, cis-12 CLA would be expected to reduce expression of $S C D 1$, which would reduce endogenous synthesis of cis-9,trans-11 CLA from trans-11 18:1. No main effects or interaction were found for other plasma FA or for the concentration of plasma triglyceride, phospholipid, or free cholesterol (Supplemental Tables S3 and S4; https://doi.org/10.3168/ jds.2016-12232).

Plasma glucose and BHB were not affected by treatments (Table 2). Plasma glucose is tightly controlled by homeostatic mechanisms in the cow, and therefore, changes were not expected. However, previous experiments in lactating cows have shown variable responses of plasma BHB to CLA. Urrutia et al. (2015) observed a $16 \%$ increase in plasma BHB during a 4-d abomasal infusion of the same CLA stock in mid-lactation cows using similar procedures and Bernal-Santos et al. (2003) observed increased plasma BHB after 9 wk of dietary CLA supplementation in early lactation cows. Others have not detected changes in plasma BHB during shortand long-term CLA supplementation (Baumgard et al., 2002a; Perfield et al., 2002; Pappritz et al., 2011). The response of plasma BHB might be specific to lactating cows due to spared BHB from reduced mammary uptake during CLA-induced MFD. Interestingly, Urrutia et al. (2015) observed increased plasma BHB with ruminal acetate infusions in lactating cows presumably due to synthesis of BHB from acetate by rumen epithe- 
Table 2. Effect of CLA and acetate on plasma concentration of key metabolic hormones, metabolites, and CLA isomers

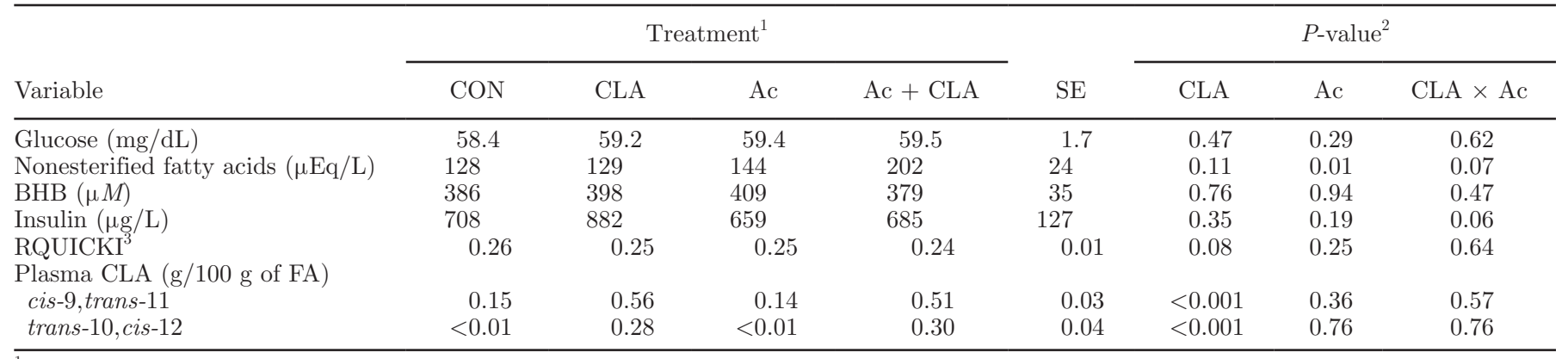

${ }^{1}$ Treatments were control (CON), $3 \mathrm{~d}$ of abomasal infusion of $10 \mathrm{~g} / \mathrm{d}$ of trans-10,cis-12 CLA and cis-9, trans-11 CLA (CLA), $3 \mathrm{~d}$ of rumen infusion of $7 \mathrm{~mol} / \mathrm{d}$ of acetate adjusted to $\mathrm{pH} 6.1$ with sodium hydroxide (Ac), and Ac + CLA ( $\mathrm{n}=8$ per treatment).

${ }^{2}$ Effect of CLA, Ac, and their interaction.

${ }^{3}$ Revised quantitative insulin sensitivity check index (RQUICKI) $=1 /[\log$ glucose $(\mathrm{mg} / \mathrm{dL})+\log$ insulin $(\mu \mathrm{U} / \mathrm{mL})+\log$ nonesterified fatty acids $(\mathrm{mmol} / \mathrm{L})+\log \mathrm{BHB}(\mathrm{mmol} / \mathrm{L})]$.

lial cells (Leighton et al., 1983) or interconversion of acetate carbon to butyrate in the rumen (van Houtert, 1993; Sutton et al., 2003). A similar increase was expected in the current experiment, but the lower intake and decreased VFA absorption may have resulted in increased ruminal wall oxidation of butyrate blunting an increase in peripheral circulation. Additional unknown mechanisms or metabolic differences due to physiological states may explain contrasting observations.

Acetate infusion increased plasma NEFA by $13 \%(P$ $=0.01$ ), and the interaction of CLA and Ac tended to increase plasma NEFA by $58 \%$ when compared with CON $(P=0.07)$, suggesting an increase in adipose tissue lipolysis (Table 2). Volatile FA, including acetate, have been reported to reduce adipose tissue lipolysis and plasma NEFA in rodents (den Besten et al., 2015). However, in lactating cows the same amount of acetate did not change plasma NEFA (Urrutia et al., 2015). The effect of acetate supply on tissue metabolism in the cow has not been well studied and requires further investigation.

In the lactating cow, some studies have shown increased milk yield with no change or small reductions in intake, suggesting a repartitioning of nutrients toward milk synthesis (de Veth et al., 2006; Odens et al., 2007; Perfield et al., 2007). However, Harvatine et al. (2009b) observed increased gene expression of lipogenic enzymes in adipose tissue of CLA-induced MFD cows and proposed that energy balance may be improved through spared nutrients from milk fat synthesis and under this condition reduced lipolysis is expected. Increased plasma NEFA has been reported during short-term infusions of CLA in some lactating cow experiments (Baumgard et al., 2000; Urrutia et al., 2015), but the response is not consistent as NEFA did not change during CLA supplementation in other stud- ies using early- and mid-lactation cows (Perfield et al., 2002; Pappritz et al., 2011). Additionally, Baumgard et al. (2002a) observed decreased NEFA response during an epinephrine challenge. In other animal models such as pigs and rodents, fat mobilization during CLA treatment might account for one of the mechanisms by which CLA reduces weight gain and body fatness (Park and Pariza, 2007). Based on no direct effect of CLA and the numerical response on plasma NEFA by the interaction of CLA and Ac (58\% increase compared with CON, $P=0.07$ ) in the current experiment, the variability in lactating cow studies may be due to an interaction of spared acetate, CLA, and physiological state.

Medium- and long-chain FA, including CLA, are known to stimulate insulin secretion through binding and activation of $\mathrm{G}$ protein-coupled receptor 40 [GPR40; Itoh et al. (2003); Schmidt et al. (2011)]. In the current experiment, a tendency was observed for an interaction of CLA and Ac on plasma insulin concentration $(P=0.06$, Table 2$)$. There was a small effect of $\mathrm{Ac}+\mathrm{CLA}$ to reduce plasma insulin and of Ac to increase plasma insulin, but CLA alone increased plasma insulin 25\% compared with CON. Previous studies have not observed a change in plasma insulin during short- or long-term CLA-induced MFD (Baumgard et al., 2000; Castañeda-Gutiérrez et al., 2005; de Veth et al., 2006), but we recently observed increased plasma insulin after 4-d infusion of the same CLA stock in low-producing cows (Urrutia et al., 2015). The explanation of these differences is unclear, but spared acetate in high-producing cows may blunt an insulin response. One of the physiological effects of insulin includes inhibiting lipolysis by preventing activation of hormone sensitive lipase, and in the current experiment insulin was reduced and NEFA was increased in Ac + CLA 
compared with CLA, demonstrating the functionality of this regulatory pathway.

In rodents, high doses of CLA result in insulin resistance presumably due to adipose tissue inflammation (Foote et al., 2010). In the current experiment, we calculated the revised quantitative insulin sensitivity check index (RQUICKI) adapted for use in cattle (Holtenius and Holtenius, 2007; Balogh et al., 2008). The CLA treatment had a tendency $(P=0.08)$ to reduce RQUICKI by $3.5 \%$, suggesting that CLA might have induced some grade of insulin resistance.

\section{Adipose Tissue Lipogenesis Assay and Gene Expression}

Lipogenic capacity and oxidation of adipose tissue was measured using a tissue explant system (Ingle et al., 1973). This technique measures lipogenic capacity by quantifying the incorporation of labeled acetate into lipids and $\mathrm{CO}_{2}$. We expected that trans-10, cis-12 CLA would reduce and acetate would increase adipose lipogenesis; however, we found a numerical reduction of lipogenesis in the CLA treatments (decreased by $50 \%$ and $68 \%$ in CLA and Ac + CLA, respectively), and surprisingly we found a numerical reduction of lipogenesis in Ac (46\% reduction, Figure 1). Oxidation of labeled acetate and the rate of lipogenesis to oxidation were not affected by treatments. In lactating cows, adipose lipogenesis decreased $72 \%$ with the same CLA stock but acetate did not change adipose lipogenesis (Urrutia et al., 2015). In lactating mammary tissue CLA decreased lipogenesis and oxidation rates in cows by 72 and $61 \%$, respectively (Baumgard et al., 2002b) and dose dependently reduced lipogenesis up to $40 \%$ in mice (Harvatine et al., 2014). The high variance in the explant system might have limited our ability to observe significant changes (19.2 and $17.5 \%$ average coefficient of variation for lipogenesis and oxidation, respectively). However, the numerical decrease is in agreement with decreased expression of lipogenic enzymes described below.

Acetate reduces adipose lipogenesis capacity through a PPAR $\gamma$-dependent mechanism in rodent models (den Besten et al., 2015) and evidence indicates that shortchain FA, including acetate, signal through GPR-41 and GPR-43 to regulate lipid metabolism in adipose, muscle, and liver tissue (reviewed by den Besten et al., 2013). In the cow, GPR-41 is upregulated in adipose tissue after parturition (Lemor et al., 2009); however, it is unclear if acetate plays a role other than being an energy and carbon source in the cow and if physiological state would influence acetate signaling and metabolism.

Conjugated linoleic acid reduced expression of SREBP1c, PPAR $\gamma 2, F A S N, A C C, L P L$, and SCD1 $(P$ $<0.05)$ and tended to reduce $S 14(P=0.07)$ in adipose
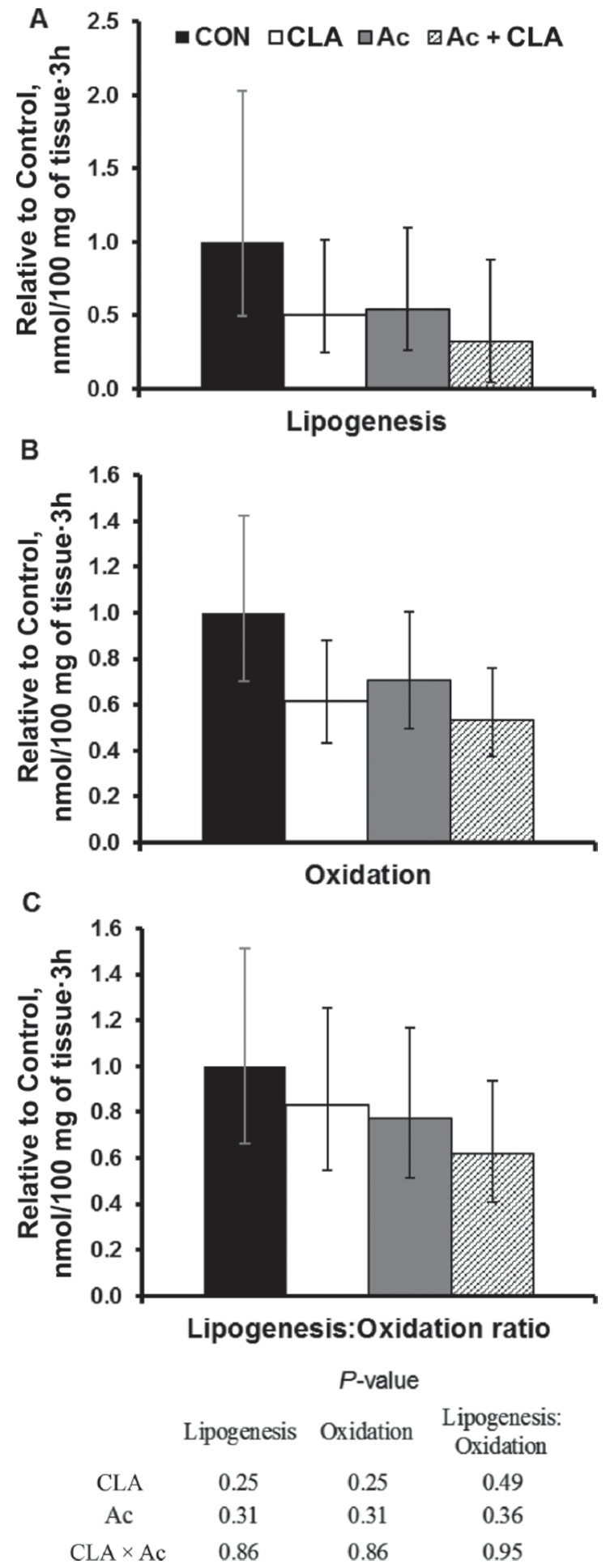

Figure 1. Effect of CLA, acetate, and their interaction on rates of lipogenesis, oxidation, and lipogenesis to oxidation ratio by adipose tissue explants. Treatments were control (CON), $3 \mathrm{~d}$ of abomasal infusion of $10 \mathrm{~g} / \mathrm{d}$ of trans-10,cis-12 CLA and cis-9,trans-11 CLA (CLA), 3 $\mathrm{d}$ of rumen infusion of $7 \mathrm{~mol} / \mathrm{d}$ of acetate adjusted to $\mathrm{pH} 6.1$ with sodium hydroxide (Ac), and Ac + CLA ( $\mathrm{n}=8$ per treatment). Utilization of ${ }^{14} \mathrm{C}$-acetate was assayed. Values are LSM $\pm \mathrm{SE}$ of logarithmic backtransformed data and are expressed relative to CON. The $P$-values for the effect of each factor (CLA, Ac, and their interaction) are shown. 
tissue (Figure 2). The effect of CLA on adipose gene expression in the current experiment is comparable to the effect of CLA on lactating mammary tissue in cows and mice (Baumgard et al., 2002b; Harvatine and Bauman, 2006; Foote et al., 2010) and the effect of CLA on adipose tissue in mice and pigs (Ostrowska et al., 1999; Foote et al., 2010).

Peroxisome proliferator activated receptor gamma is a member of the nuclear receptor family and regulates adipose differentiation and gene expression and CLA is a ligand for PPAR $\gamma$ (Belury et al., 2002). In humans and rodents, both PPAR $\gamma$ transcripts, PPAR $\gamma 1$ and PPAR $\gamma 2$, are highly expressed in adipose tissue (VidalPuig et al., 1996; Vidal-Puig et al., 1997); however, PPAR $\gamma 2$ is more sensitive to nutritional regulation. In the current experiment, $P P A R \gamma 2$, but not $P P A R \gamma 1$, was decreased by CLA, suggesting that adipose $P P A R \gamma 2$ is sensitive to CLA and may be involved in modification of downstream lipogenic target genes.

Contrary to our expectations, acetate reduced expression of FASN, ACC, leptin, and $S C D 1(P<0.05)$ and tended to reduce expression of $S 14, P P A R \gamma 1$, and $L P L(P<0.10$, Figure 2$)$. Reduced expression of lipogenic enzymes in response to acetate has been reported in rodent liver and adipose tissue through a PPAR $\gamma$ dependent mechanism (Yamashita et al., 2007; den Besten et al., 2015) and consumption of acetic acid reduced BW, body mass index, waist circumference, and visceral fat in humans (Kondo et al., 2009). In lactating cows we failed to observe changes in adipose lipogenic gene expression after $4 \mathrm{~d}$ of rumen acetate infusion, although acetate increased milk fat yield and may have limited availability of acetate to adipose tissue (Urrutia et al., 2015).

Lastly, the interaction of CLA and acetate tended to reduce adipose tissue lipogenic signaling as expression of $S R E B P 1 c$ was decreased $(P<0.10)$, and FABP 4 increased $(P=0.05)$ in Ac + CLA compared with Ac and CLA alone (Figure 2). These data are contrary to our expectations as it was hypothesized that increased expression of lipogenic genes in adipose, including $S R E B P 1 c$ and $S 14$, in lactating cows during CLA-induced MFD was a response to spared nutrients (Harvatine et al., 2009b).

It is important to mention that the cannulated nonlactating cows used in the current experiment were not homogeneous in terms of BW, basal diet fed, and days to calving, therefore, may have differed physiologically. Also, tissue uptake of CLA in nonlactating cows may differ from lactating cows; and it is also known that subcutaneous adipose tissue is not as metabolically active as other depots, but challenges exist in obtaining mesenteric and visceral adipose tissue for this type of an experiment.
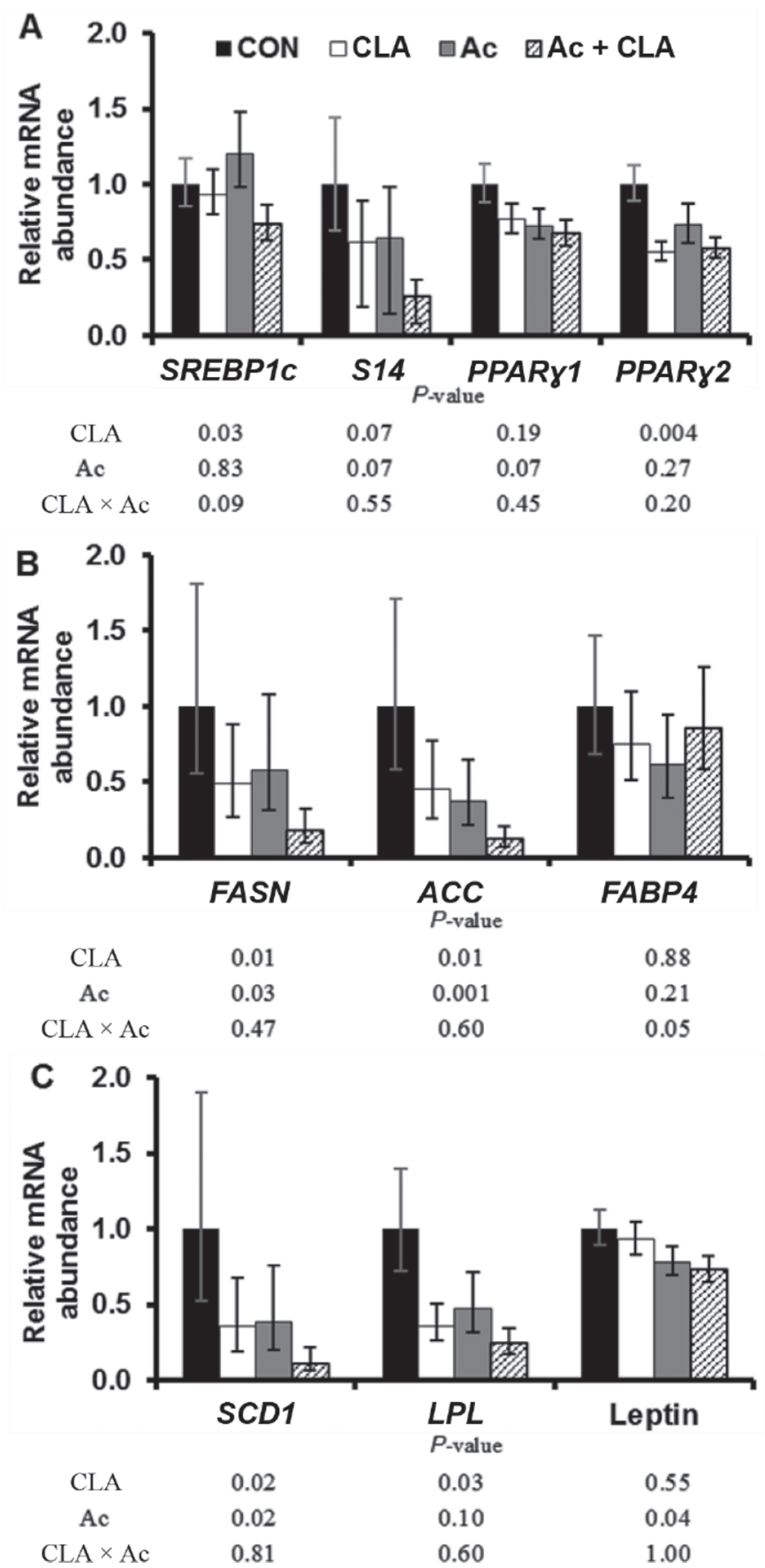

Figure 2. Effect of CLA, acetate, and their interaction on gene expression of mRNA of key lipogenic transcription regulators and enzymes in adipose tissue. Treatments were control (CON), $3 \mathrm{~d}$ of abomasal infusion of $10 \mathrm{~g} / \mathrm{d}$ of trans-10,cis-12 CLA and cis-9,trans-11 CLA (CLaA), $3 \mathrm{~d}$ of rumen infusion of $7 \mathrm{~mol} / \mathrm{d}$ of acetate adjusted to $\mathrm{pH} 6.1$ with sodium hydroxide (Ac), and Ac + CLA ( $\mathrm{n}=8$ per treatment). Values are LSM $\pm \mathrm{SE}$ of logarithmic back-transformed data and expressed relative to CON. The $P$-values for the effect of each factor (CLA, Ac, and their interaction) are shown below each gene. $S R E B P 1=$ sterol response element binding protein $1 ; S 14=$ thyroid hormone responsive spot $14 ; P P A R \gamma=$ peroxisome proliferator-activated receptor gamma; $F A S N=$ fatty acid synthase; $A C C=$ acetyl-CoA carboxylase; $F A B P 4=$ fatty acid binding protein $4 ; S C D 1$ $=$ stearoyl-CoA desaturase $1 ; L P L=$ lipoprotein lipase. 


\section{CONCLUSIONS}

In the nonlactating cow, adipose tissue is sensitive to the anti-lipogenic effects of trans-10,cis-12 CLA at the transcription level, but acetate does not stimulate adipose lipogenesis. Additionally, an interaction of acetate and CLA on stimulating adipose lipogenesis was not observed using the nonlactating cow model. Contrasting observations between the effect of CLA and acetate compared with the CLA-induced MFD lactating cow might be explained by physiological state differences. The effect of acetate supply on adipose metabolism and lipogenesis has not been well studied in the modern cow and requires further investigation.

\section{ACKNOWLEDGMENTS}

The authors thank Felipe Pino for his assistance in performing adipose tissue biopsies and Michel Baldin, Liying Ma, Mutian Niu, and Daniel Rico for their technical assistance during experimental periods (Penn State University, University Park, PA). In addition, we thank Dale Bauman and Arnulf Troescher (BASF) for helpful discussion, and BASF for the CLA stock and partial financial support of the study.

\section{REFERENCES}

AOAC International. 2000. Official Methods of Analysis. 17th ed. AOAC International, Arlington, VA.

Baldwin, R. 1995. Modeling Ruminant Digestion and Metabolism. Springer Science \& Business Media, Berlin/Heidelberg, Germany.

Ballou, M. A., R. C. Gomes, S. O. Juchem, and E. J. DePeters. 2009 Effects of dietary supplemental fish oil during the peripartum period on blood metabolites and hepatic fatty acid compositions and total triacylglycerol concentrations of multiparous Holstein cows. J. Dairy Sci. 92:657-669.

Balogh, O., O. Szepes, K. Kovacs, M. Kulcsar, J. Reiczigel, J. Alcazar, M. Keresztes, H. Febel, J. Bartyik, and S. G. Fekete. 2008. Interrelationships of growth hormone AluI polymorphism, insulin resistance, milk production and reproductive performance in HolsteinFriesian cows. Vet. Med. (Praha) 53:604-616.

Bauman, D. E., R. E. Brown, and C. L. Davis. 1970. Pathways of fatty acid synthesis and reducing equivalent generation in mammary gland of rat, sow, and cow. Arch. Biochem. Biophys. 140:237-244.

Bauman, D. E., D. L. Ingle, R. W. Mellenberger, and C. L. Davis. 1973. Factors affecting in vitro lipogenesis by bovine mammary tissue slices. J. Dairy Sci. 56:1520-1525.

Baumgard, L. H., B. A. Corl, D. A. Dwyer, and D. E. Bauman. 2002a. Effects of conjugated linoleic acids (CLA) on tissue response to homeostatic signals and plasma variables associated with lipid metabolism in lactating dairy cows. J. Anim. Sci. 80:1285-1293.

Baumgard, L. H., B. A. Corl, D. A. Dwyer, A. Saebo, and D. E. Bauman. 2000. Identification of the conjugated linoleic acid isomer that inhibits milk fat synthesis. Am. J. Physiol. Regul. Integr. Comp. Physiol. 278:R179-R184.

Baumgard, L. H., E. Matitashvili, B. A. Corl, D. A. Dwyer, and D. E. Bauman. 2002b. Trans-10, cis-12 conjugated linoleic acid decreases lipogenic rates and expression of genes involved in milk lipid synthesis in dairy cows. J. Dairy Sci. 85:2155-2163.

Baumgard, L. H., J. K. Sangster, and D. E. Bauman. 2001. Milk fat synthesis in dairy cows is progressively reduced by increasing supplemental amounts of trans-10, cis-12 conjugated linoleic acid (CLA). J. Nutr. 131:1764-1769.

Belury, M. A., S. Y. Moya-Camarena, M. Lu, L. Shi, L. M. Leesnitzer, and S. G. Blanchard. 2002. Conjugated linoleic acid is an activator and ligand for peroxisome proliferator-activated receptor-gamma. Nutr. Res. 22:817-824.

Bernal-Santos, G., J. W. Perfield Ii, D. M. Barbano, D. E. Bauman, and T. R. Overton. 2003. Production responses of dairy cows to dietary supplementation with conjugated linoleic acid (CLA) during the transition period and early lactation. J. Dairy Sci. 86:32183228 .

Castañeda-Gutiérrez, E., T. R. Overton, W. R. Butler, and D. E. Bauman. 2005. Dietary supplements of two doses of calcium salts of conjugated linoleic acid during the transition period and early lactation. J. Dairy Sci. 88:1078-1089.

Choi, S. H., D. T. Silvey, B. J. Johnson, M. E. Doumit, K. Y. Chung, J. E. Sawyer, G. W. Go, and S. B. Smith. 2014. Conjugated linoleic acid (t-10, c-12) reduces fatty acid synthesis de novo, but not expression of genes for lipid metabolism in bovine adipose tissue ex vivo. Lipids 49:15-24.

Corl, B. A., S. A. Mathews Oliver, X. Lin, W. T. Oliver, Y. Ma, R. J. Harrell, and J. Odle. 2008. Conjugated linoleic acid reduces body fat accretion and lipogenic gene expression in neonatal pigs fed low- or high-fat formulas. J. Nutr. 138:449-454.

de Veth, M., E. Castaneda-Gutierrez, D. Dwyer, A. Pfeiffer, D. Putnam, and D. Bauman. 2006. Response to conjugated linoleic acid in dairy cows differing in energy and protein status. J. Dairy Sci. 89:4620-4631.

den Besten, G., A. Bleeker, A. Gerding, K. van Eunen, R. Havinga, T. H. van Dijk, M. H. Oosterveer, J. W. Jonker, A. K. Groen, D. J. Reijngoud, and B. M. Bakker. 2015. Short-chain fatty acids protect against high fat diet induced obesity via a PPAR gamma dependent switch from lipogenesis to fat oxidation. Diabetes 64:2398-2408.

den Besten, G., K. van Eunen, A. K. Groen, K. Venema, D. J. Reijngoud, and B. M. Bakker. 2013. The role of short-chain fatty acids in the interplay between diet, gut microbiota, and host energy metabolism. J. Lipid Res. 54:2325-2340.

Emery, R. S. 1973. Biosynthesis of milk fat. J. Dairy Sci. 56:1187-1195.

Foote, M. R., S. L. Giesy, G. Bernal-Santos, D. E. Bauman, and Y. R Boisclair. 2010. t10,c12-CLA decreases adiposity in peripubertal mice without dose-related detrimental effects on mammary development, inflammation status, and metabolism. Am. J. Physiol. Regul. Integr. Comp. Physiol. 299:R1521-R1528.

Harvatine, K. J., and D. E. Bauman. 2006. SREBP1 and thyroid hormone responsive spot 14 (S14) are involved in the regulation of bovine mammary lipid synthesis during diet-induced milk fat depression and treatment with CLA. J. Nutr. 136:2468-2474.

Harvatine, K. J., and D. E. Bauman. 2011. Characterization of the acute lactational response to trans-10, cis-12 conjugated linoleic acid. J. Dairy Sci. 94:6047-6056.

Harvatine, K. J., Y. R. Boisclair, and D. E. Bauman. 2009a. Recent advances in the regulation of milk fat synthesis. Animal 3:40-54.

Harvatine, K. J., J. W. Perfield 2nd, and D. E. Bauman. 2009b. Expression of enzymes and key regulators of lipid synthesis is upregulated in adipose tissue during CLA-induced milk fat depression in dairy cows. J. Nutr. 139:849-854.

Harvatine, K. J., M. M. Robblee, S. R. Thorn, Y. R. Boisclair, and D. E. Bauman. 2014. Trans-10, cis-12 CLA dose-dependently inhibits milk fat synthesis without disruption of lactation in C57BL/6J mice. J. Nutr. 144:1928-1934.

Holtenius, P., and K. Holtenius. 2007. A model to estimate insulin sensitivity in dairy cows. Acta Vet. Scand. 49:29.

Ingle, D. L., D. E. Bauman, R. W. Mellenberger, and D. E. Johnson. 1973. Lipogenesis in the ruminant: effect of fasting and refeeding on fatty acid synthesis and enzymatic activity of sheep adipose tissue. J. Nutr. 103:1479-1488.

Itoh, Y., Y. Kawamata, M. Harada, M. Kobayashi, R. Fujii, S. Fukusumi, K. Ogi, M. Hosoya, Y. Tanaka, and H. Uejima. 2003 Free fatty acids regulate insulin secretion from pancreatic $\beta$ cells through GPR40. Nature 422:173-176. 
Karkalas, J. 1985. An improved enzymic method for the determination of native and modified starch. J. Sci. Food Agric. 36:1019-1027.

Kondo, T., M. Kishi, T. Fushimi, S. Ugajin, and T. Kaga. 2009. Vinegar intake reduces body weight, body fat mass, and serum triglyceride levels in obese Japanese subjects. Biosci. Biotechnol. Biochem. 73:1837-1843.

Kramer, J. K., V. Fellner, M. E. Dugan, F. D. Sauer, M. M. Mossoba, and M. P. Yurawecz. 1997. Evaluating acid and base catalysts in the methylation of milk and rumen fatty acids with special emphasis on conjugated dienes and total trans fatty acids. Lipids $32: 1219-1228$.

Leighton, B., A. R. Nicholas, and C. I. Pogson. 1983. The pathway of ketogenesis in rumen epithelium of the sheep. Biochem. J. 216:769-772.

Lemor, A., A. Hosseini, H. Sauerwein, and M. Mielenz. 2009. Transition period-related changes in the abundance of the mRNAs of adiponectin and its receptors, of visfatin, and of fatty acid binding receptors in adipose tissue of high-yielding dairy cows. Domest. Anim. Endocrinol. 37:37-44.

Odens, L. J., R. Burgos, M. Innocenti, M. J. VanBaale, and L. H. Baumgard. 2007. Effects of varying doses of supplemental conjugated linoleic acid on production and energetic variables during the transition period. J. Dairy Sci. 90:293-305.

Ostrowska, E., M. Muralitharan, R. F. Cross, D. E. Bauman, and F. R. Dunshea. 1999. Dietary conjugated linoleic acids increase lean tissue and decrease fat deposition in growing pigs. J. Nutr. 129:2037-2042.

Pappritz, J., U. Meyer, R. Kramer, E.-M. Weber, G. Jahreis, J. Rehage, G. Flachowsky, and S. Danicke. 2011. Effects of long-term supplementation of dairy cow diets with rumen-protected conjugated linoleic acids (CLA) on performance, metabolic parameters and fatty acid profile in milk fat. Arch. Anim. Nutr. 65:89-107.

Park, Y., and M. W. Pariza. 2007. Mechanisms of body fat modulation by conjugated linoleic acid (CLA). Food Res. Int. 40:311-323.

Perfield, J. W., G. Bernal-Santos, T. Overton, and D. Bauman. 2002. Effects of dietary supplementation of rumen-protected conjugated linoleic acid in dairy cows during established lactation. J. Dairy Sci. 85:2609-2617.

Perfield, J. W. 2nd, A. L. Lock, J. M. Griinari, A. Saebo, P. Delmonte, D. A. Dwyer, and D. E. Bauman. 2007. Trans-9, cis-11 conjugated linoleic acid reduces milk fat synthesis in lactating dairy cows. J. Dairy Sci. 90:2211-2218.

Raabo, E., and T. Terkildsen. 1960. On the enzymatic determination of blood glucose. Scand. J. Clin. Lab. Invest. 12:402-407.

Rico, D. E., and K. J. Harvatine. 2013. Induction of and recovery from milk fat depression occurs progressively in dairy cows switched between diets that differ in fiber and oil concentration. J. Dairy Sci. 96:6621-6630.

Schmidt, J., K. Liebscher, N. Merten, M. Grundmann, M. Mielenz, H. Sauerwein, E. Christiansen, M. E. Due-Hansen, T. Ulven, and S. Ullrich. 2011. Conjugated linoleic acids mediate insulin release through islet $\mathrm{G}$ protein-coupled receptor FFA1/GPR40. J. Biol. Chem. 286:11890-11894

Sheperd, A. C., and D. Combs. 1998. Long-term effects of acetate and propionate on voluntary feed intake by midlactation cows. J. Dairy Sci. 81:2240-2250.

Spires, H. R., J. Clark, R. Derrig, and C. Davis. 1975. Milk production and nitrogen utilization in response to postruminal infusion of sodium caseinate in lactating cows. J. Nutr. 105:1111-1121.

Sutton, J. D., M. Dhanoa, S. Morant, J. France, D. Napper, and E. Schuller. 2003. Rates of production of acetate, propionate, and butyrate in the rumen of lactating dairy cows given normal and low-roughage diets. J. Dairy Sci. 86:3620-3633.

Thering, B. J., D. Graugnard, P. Piantoni, and J. Loor. 2009. Adipose tissue lipogenic gene networks due to lipid feeding and milk fat depression in lactating cows. J. Dairy Sci. 92:4290-4300.

Urrutia, N. L., M. Baldin, Y. Ying, and K. J. Harvatine. 2015. Effect of acetate and trans-10, cis-12 CLA on milk production in lactating dairy cows. J. Dairy Sci. 98(Suppl. 2):147.

van Houtert, M. F. J. 1993. The production and metabolism of volatile fatty acids by ruminants fed roughages: A review. Anim. Feed Sci. Technol. 43:189-225.

Van Soest, P. J., J. B. Robertson, and B. A. Lewis. 1991. Methods for dietary fiber, neutral detergent fiber, and nonstarch polysaccharides in relation to animal nutrition. J. Dairy Sci. 74:3583-3597.

Vidal-Puig, A., M. Jimenez-Liñan, B. B. Lowell, A. Hamann, E. Hu, B. Spiegelman, J. S. Flier, and D. E. Moller. 1996. Regulation of PPAR gamma gene expression by nutrition and obesity in rodents. J. Clin. Invest. 97:2553-2561.

Vidal-Puig, A. J., R. V. Considine, M. Jimenez-Liñan, A. Werman, W. J. Pories, J. F. Caro, and J. S. Flier. 1997. Peroxisome proliferatoractivated receptor gene expression in human tissues. Effects of obesity, weight loss, and regulation by insulin and glucocorticoids. J. Clin. Invest. 99:2416-2422.

Yamashita, H., K. Fujisawa, E. Ito, S. Idei, N. Kawaguchi, M. Kimoto, M. Hiemori, and H. Tsuji. 2007. Improvement of obesity and glucose tolerance by acetate in Type 2 diabetic Otsuka Long-Evans Tokushima Fatty (OLETF) rats. Biosci. Biotechnol. Biochem. $71: 1236-1243$. 